Mateusz Chmurski

\title{
Trans/figuracje nowoczesności? Spory o twórczość Marii Komornickiej-Piotra Odmieńca Własta
}

Jak stwierdziła już w 2010 r. Inga Iwasiów [2010: 12], „wszyscy (prawie wszyscy) piszący o Komornickiej musieli chcieć czegoś więcej niż wykonania pracy nad tekstem”. Nie sposób nie przyznać jej racji. Świadczą o tym nie tylko liczne monografie czy rozdziały studiów, rozpraw, prac magisterskich i doktorskich, ale również artykuły prasowe (od „Elle” po „Wysokie Obcasy”), wywiady czy wpisy na blogach najrozmaitszego autoramentu - w ostatnich dwóch dekadach fenomen Marii Komornickiej-Piotra Odmieńca Własta wykroczył zdecydowanie poza ramy dyskursu akademickiego. Stał się zjawiskiem wyraziście obecnym w kulturze polskiej. Co znamienne, na półkach księgarń i bibliotek częściej można dziś jednak odnaleźć prace o Komornickiej-Odmieńcu Właście niż dzieła jej/jego samej/samego; Ewa Paczoska [2011] nie waha się wręcz mówić o nadprodukcji interpretacji, nieraz upraszczających fenomen życia i twórczości autora/autorki. Brak ciągle pełnego wydania jego/jej pism, w szczególności zaś tak znaczącej dla interpretacji Księgi poezji idyllicznej, której nawet tytuł zapisywany bywa różnorako. Brak jednolitej interpretacji przemiany Marii Komornickiej w Piotra Odmieńca Własta. Znaczenie legendarnego gestu spalenia damskiego ubioru w poznańskim hotelu 
Bazar w roku 1907 bywa relatywizowane wobec wcześniejszych zaszłości i kwestionowane w świetle wydanych niedawno listów do matki [Komornicka 2011]. Brak wreszcie nawet zgody co do rodzaju gramatycznego, za pomocą którego omawiana jest jej/ jego twórczość: niektórzy autorzy formy męskie i żeńskie stosują łącznie, w zależności od kontekstu, inni obierają natomiast wyłącznie jedną z nich (w niniejszym arykule stosowane będą więc obydwie). Słowem, mimo podjętych dotychczas wysiłków badawczych, edytorskich i popularyzatorskich do dziś nie traci na ważności pytanie krewnej Odmieńca, Marii Dernałowicz [1977: 81 i nn.]: „w jakąż gramatykę ująć przeszłość”.

Bezspornie widać dziś, że twórczość Komornickiej-Odmieńca Własta wymyka się ustalonym kategoryzacjom metodologicznym czy periodyzacyjnym. Wymaga uruchomienia zdecydowanie szerszych kontekstów badawczych i wskazuje na potrzebę rewizji dotychczasowych ustaleń: biograficznych, literaturo-, a wręcz i kulturoznawczych. Zawiera w sobie subwersywny potencjał, wymagający szczególnego wysiłku poznawczego. Tym samym jest więc nośnikiem wyznania, które staje się wyzwaniem dla polskiej humanistyki. Wymusza zaangażowanie w pracę nie tylko nad tekstem, ale i nad kontekstem: epoki, danej intepretacji, a także najbliższej nam współczesności.

Spory o twórczość Komornickiej-Odmieńca Własta wyróżniają się jako być może jeden z najciekawszych - a z pewnością jeden z najbardziej kontrowersyjnych - rozdziałów polskiego literaturoznawstwa ostatnich dziesięcioleci. Choć pojawiły się cząstkowe próby ujęcia najważniejszych zagadnień dotychczasowego stanu badań [zob. np. Filipiak 2006: 9-69, 76-97; Helbig-Mischewski 2010: 39-79; Paczoska 2011; Zdanowicz 2004 i in.], to krytyczne podsumowanie ostatniego ćwierćwiecza recepcji czeka wciąż na swoich badaczy. Nie miejsce tu jednak na syntetyczny przegląd dotychczasowych ustaleń czy szersze wydobycie trybów, w jakich dokonuje się przywracanie zapomnianego przez lata w literaturze polskiej Odmieńca. Wydaje się bowiem, że proces ten trwa i trwać będzie jeszcze długo: co najmniej do chwili, w której do księgarń zawitają Pisma Komornickiej-Odmieńca Własta. Wbrew niedokonanym aspektom recepcji już dziś warto wszak zapytać: czy 
już na tym etapie możliwe jest krytyczne spojrzenie na tę bogatą, choć selektywnie rozwijaną recepcję? Wydaje się to tym bardziej uzasadnione, że powstałe dotychczas monografie ukazują co najmniej trzy konteksty, „obszary odmienności” czy nieoczywistości w obrazie dziedzictwa kulturowego nowoczesności, i to nie tylko polskiej, do których (re)definicji zmusza ta twórczość.

Po pierwsze, chodzi o refleksję nad podziałami rodzajowymi i gatunkowymi, a w szczególności nad znaczeniem pisarstwa autobiograficznego: gatunku, a może raczej praktyki i dyskursu podających w wątpliwość granice literatury, biografistyki i kanonu kultury [zob. Gilmore 2001; Bogaert i Lejeune 2003, 2005; Rodak 2011]. Po drugie, recepcja twórczości Odmieńca pozwala zadać pytanie o zakres i rozumienie literackiego polskiego modernizmu, a więc o kwestię nieustannie dyskutowaną w literaturoznawstwie krajowym ostatnich dziesięcioleci [por. np. Nycz 1997; Bolecki 2012]. Po trzecie wreszcie, co najważniejsze, prace poświęcone Komornickiej-Odmieńcu Włastowi ukazują jednocześnie wachlarz postaw badaczy wobec twórczości przekraczającej społeczno-kulturowe normy przyjmowane zarówno w epoce, jak i, poniekąd, współcześnie. Pośrednio lub bezpośrednio pozwalają obserwować pozycje historyków literatury i kultury, a także stopień ich zaangażowania nie tylko w przedmiot pracy, ale i we współczesną rzeczywistość społeczno-kulturową. Zmuszają do głębszej refleksji nad pozycją badaczek i badaczy, „późnych wnuków" Odmieńca, prowadzą do problematyzacji obranych podejść metodologicznych i zastanowienia się nad potencjalną „przemocą interpretacji”, na którą na przykładzie Komornickiej zwrócił uwagę kilka lat temu Ryszard Wołosiuk [2010]. Opierając się na wybranych pracach o życiu i twórczości Komornickiej-Odmieńca Własta, które powstały w ostatnich dwóch dekadach, tym trzem kontekstom - a właściwie płaszczyznom sporu wykraczającym daleko poza historię literatury - chciałbym poświęcić niniejszy artykuł.

\section{Negocjowanie odmienności: od kontraktu ...}

Na wstępie powróćmy na chwilę do pierwszego powojennego wydania Komornickiej-Odmieńca Własta. W liście z 2 lutego 
1961 r. do jego/jej siostry, Anieli Komornickiej, Stanisław Pigoń [cyt. za: Filipiak 2006: 499, przyp. 31 $]^{1}$ następująco tłumaczy swe decyzje edytorskie w trakcie przygotowań do publikacji w Archiwum Literackim: „W. Szanowna Pani, skoro się siostra Pani zdecydowała zostać literatką, eo ipso przystała na to, że zarówno jej twórczość, jak i osobowość będzie przedmiotem ogólnej uwagi, nawet wścibstwa”.

Zasady wydania wyjaśnione są tu jak najklarowniej: jako osoba publiczna Komornicka musiała spodziewać się, że nie tylko za życia, gdy było jej dane prawo do dyskusji czy obrony, ale również - a może w szczególności - po śmierci jej biografia i teksty mogą stać się obiektem rozważań i roztrząsań wszelkiej maści, aż po „wścibstwo”. To krytycy, badacze i czytelnicy zawyrokują, jak przeżyła swoje życie i co warte są jej pisma. Najbardziej osobiste ze świadectw o jej losie przynależą - zdaniem Pigonia - do dziedzictwa polskiej kultury. Z tego powodu badacz, przyjmując niejako rolę super ego autorki/autora, które współstanowią elity uniwersyteckie, bierze na siebie decyzję o upublicznieniu tych świadectw [Filipiak 2006: 83]. Nic więc dziwnego, że wydanie z roku 1964 opatrzone zostało potrójnym imprimatur: biograficznym, medycznym i estetycznym. Świadectwa bliskich (siostry, brata) ukazać miały jak najwierniejszy obraz jej/jego życia, przydane do nich zapiski Aleksandra Oszackiego, kuzyna-lekarza Odmieńca, przedstawiały zarys jej/jego choroby psychicznej, a wybór tekstów zyskał wreszcie literaturoznawczą sankcję pióra samego Pigonia.

Rekonstruując dzieje tej publikacji, Izabela Filipiak [2006: 83 i nn.] poddała analizie nie tylko osobiste zasługi Pigonia, ale również jego motywacje (jak przyjaźń z Oszackim, towarzyszem niedoli profesora w obozie w Sachsenhausen) oraz zdeponowaną w Muzeum Literatury w Warszawie korespondencję między badaczem a Anielą Komornicką. W ten sposób można dostrzec fascynujące negocjacje co do obrazu autorki/autora, jaki potomności przekazać miała publikacja w Archiwum Literackim, a w szczególności rozpisany w listach swoisty kontrakt dziedziczki rodu Komornickich z Pigoniem jako dysponentem wiedzy literaturo- 
znawczej i władzy nad środkami jej publikacji. Kontrakt, a więc jak przypomina Filipiak - kompromis. Dodajmy, że jego podstawą jest etyczna (prywatne/upublicznione), estetyczna (artystycznie nie/udane) a wręcz i medyczna (zdrowie/szaleństwo) ocena stopnia „obszarów odmienności” w pismach Komornickiej-Odmieńca Własta, jaki publiczność skłonna jest - w mniemaniu wydawców - przyjąć. W ten sposób Pigoń i Aniela Komornicka stanowią pierwszą parę aktorów w procesie przywracania Odmieńca na scenę kultury polskiej. W ich przypadku zaangażownie obydwu stron wyrażone zostało stosunkowo klarownie, choć w ramach prywatnej korespondencji. Przypadek ten skłania zaś do postawienia pytania o obecność podobnych mechanizmów w późniejszej recepcji autorki/autora.

Po pierwsze, warto zauważyć, że od momentu współpracy Pigonia z siostrą autora/autorki właściwie brak pracy, w której historia jej/jego życia nie byłaby spleciona z interpretacją twórczości, przesłanki piszących nie zawsze zostały jasno sformułowane. Losy Komornickiej-Odmieńca Własta od kilku dziesięcioleci poddawane są kontrastywnej, lustrzanej lekturze w świetle najrozmaitszych teorii, metodologii i dyscyplin: od psychologizmu [Podraza-Kwiatkowska 1969, 1996] po antypsychiatrię [Janion 1982], psychoanalizę w duchu Ericha Fromma i Jungowską mandalę [Boniecki 1996], Jacques’a Lacana, Jacques’a Derridę i performatykę płci kulturowej w ujęciu Judith Butler [Filipiak 2006] czy psychiatrię humanistyczną [Helbig-Mischewski 2010]. Jak zauważa Iwasiów [2010: 10], tak szeroki wachlarz propozycji jest w pewnym sensie zrozumiały, ponieważ w przypadku Komornickiej-Odmieńca Własta „konwersja/subwersja płciowa” wiąże się zarazem z zapętleniem gatunków literackich $\mathrm{w}$ „laboratorium znaczenia” „mocy illokucyjnych oraz performatywności literatury”. Podobnie jak w negocjacjach Pigonia z Anielą Komornicką każda dyskusja o twórczości Komornickiej-Odmieńca Własta uwzględnia - pośrednio bądź bezpośrednio - nie tylko szereg przesłanek interpretacyjnych właściwych dyscyplinie, ale również określoną pozycję badacza wobec norm i konwencji estetycznych, genologicznych czy medycznych. Przywołajmy trzy przykładowe podejścia. 


\section{2. ...po aktualizacje, prospekcje i retrospekcje}

W jednej z najobszerniejszych dotychczas wydanych książek poświęconych twórczości Komornickiej-Odmieńca Własta niemiecka literaturoznawczyni Brigitta Helbig-Mischewski [2010: 18] zaznacza już na wstępie, że przy polskim wydaniu pracy wprowadziła ton zdecydowanie bardziej osobisty, który określić można mianem aktualizacji dzieła Komornickiej-Odmieńca Własta w kontekście współczesnym. Przy interpretacji jego/jej dzieła badaczka zdecydowała się bowiem ukazać także cząstkę swoich własnych przekonań. Na przykład gdy intepretuje wydany w Poznaniu w roku 1895 szkic dramatyczny pt. Skrzywdzeni, dodaje: „Godna uwagi jest także kwestia nieumiejętności partnera męskiego radzenia sobie z wielkością kobiety - jakże ważna, zapewne, dla samej Marii, ale i dla nas, dziś" [Helbig-Mischewski 2010: 157]. W podobnych uwagach - niezależnie od ustaleń badawczych - w obręb swojej wypowiedzi badaczka wprowadza charakterystyczne modalności: dokonuje jawnie personalizacji i uwspółcześnienia wyprowadzanej z tekstów Odmieńca tezy. Przy okazji refleksji nad powstałymi wiek temu dziełami otwarcie wzmiankuje swoją pozycję na współczesnej mapie sporów ideologicznych i społeczno-kulturowych. Co niezwykle ważne, klarownie zaznacza przy tym granice między interpretacją tekstu, analogiami z losem autora/autorki a swym własnym zaangażowaniem we współczesny kontekst:

Tam gdzie zabrakło rewolucyjnego zapału lub został on stłumiony, a ujścia energii zaryglowane, tam bohaterka tekstu i życia stopniowo osuwa się $\mathrm{w}$ autoagresję i unicestwienie siebie. Punktem kulminacyjnym tych narracji zablokowanych, stanowiących przeciwieństwo narracji rebelianckich, będą Biesy $[\ldots]$. Fenomen ten znany jest i w dzisiejszym społeczeństwie - podobne demony nawiedzają np. pozbawionych zatrudnienia czy też dzieci nieprzeciętnie uzdolnione [...]. Ucieczką od braku perspektyw jest albo gniew skierowany przeciwko sobie (depresja), albo przeciwko innym (agresja). [Helbig-Mischewski 2010: 220] 
„Podobne” czy „i w”: porównanie i analogia są tu prostym, acz skutecznym zabiegiem pozwalającym na pogodzenie dyskursu badawczego z zaangażowaniem w dzisiejsze spory. Helbig-Mischewski, jak sama zaznacza, zainspirowała się rozwinięciem osobistego tonu w wiernej tezom, intuicji i zaangażowaniu Marii Janion pracy Filipiak [2006]. Autorka ta często zestawia bowiem wprost krytyczny potencjał dzieł Komornickiej-Odmieńca Własta ze współczesnymi problemami polskiego społeczeństwa. Przeprowadza w ten sposób nie tylko aktualizację, ale również interpretację postulatywną, czy wręcz prospektywną. Jej uzasadnienie odnajduje w krytycznym potencjale pism samej/samego Komornickiej-Odmieńca Własta:

Komornicka nigdy nie została właściwie pochowana w obszarze kultury, a to znaczy, że nie została zintegrowana w taki sposób, który pozwoliłby jej spocząć w spokoju - dlatego wraca, żeby nas nawiedzać. [Filipiak 2006: 218]

W świetle analiz żałoby kulturowej w pracach Slavoja Žižka Filipiak zestawia w ten sposób pamięć o transgresywnej twórczości Komornickiej z traumą Jedwabnego. Zacytujmy inny znamienny przykład: „W Powrocie ideatów Komornicka zajmuje się przestrzenią symboliczną języka, pokazuje jak «Żyd» jest konstruowany w języku. I to czyni zeń współczesną nam humanistkę" [Filipiak 2006: 169].

Obserwując „obszary odmienności” poprzedniego stulecia, badaczka zwraca uwagę na ich stałą obecność w kulturze polskiej: od antysemityzmu i „mowy nienawiści” [Filpiak 2006: 313] po aluzje do odbieranej jako kontrowersyjna przez niektóre grupy społeczne i polityczne działalności Andy Rottenberg [Filipiak 2006: 179] czy wyparte z kultury polskiej (homo)biografie:

Czy nadal będziemy się upierać, że dwóm najbardziej oryginalnym autorkom [Narcyzie Żmichowskiej i Komornickiej - M.Ch.] na przestrzeni XIX wieku przytrafiła się ta sama psychiczna przypadłość? Czy to raczej kwestia kultury? Czy nie jest przypadkiem tak, że obie reprezentują taką twórczą 
osobowość, która jest w obrębie polskiej kultury całkiem bezużyteczna? Można ją ubrać w surdut - lub go z niej zdjąć, można jej obciąć włosy we wspomnieniu - lub zapuścić. I to wszystko. Co tu po niej? Jest osobą skazaną na powolną śmierć. Obojętne, jak i kiedy do niej dojdzie. [Filipiak 2006: 304-305]

Tak Filpiak w podniosłym tonie domaga się należnego miejsca dla zjawisk i dyskursów wypartych z kultury polskiej. Książkę kończy w znamienny sposób podsumowaniem-apelem Do przysztości [Filpiak 2006: 482-488]. Tym samym angażuje się świadomie w poddawanie pod refleksję konwencji literackich i społecznych wywodzących się ze stulecia, którego „prawdziwy koniec” jeszcze nie nadszedł [Paczoska 2010; Paczoska, Szleszyński, red. 2011]. Ceną za to zaangażowanie jest oczywiście możliwość zarzucenia jej subiektywności i telelogiczności interpretacji, która prowadzić ma nie tylko do ustalenia na nowo miejsca Odmieńca w kulturze polskiej, ale i do wpłynięcia w ten sposób na czytelników (scil. współczesną kulturę polską). Czy jednak jakakolwiek praca literaturoznawcza od momentu jej recepcji nie poddaje się tym samym prawom, co dowolny inny tekst w polu literatury? Czy nolens volens nie oddziałuje więc na czytelników, których grono autor jest w stanie jedynie częściowo przewidzieć? Uczciwe credo badacza wydaje mi się uczciwym odkryciem kart, w które grają wszak wszyscy zainteresowani, w tym i najbardziej zaciekli z krytyków.

Przytoczone tu pozycje badaczek zaangażowanych w teraźniejszość polskiej kultury odbiegają przy tym wyraźnie od pierwszej monografii Komornickiej-Odmieńca Własta pióra Edwarda Bonieckiego [1996]. Badacz, sytuując „Marynię” (jak określa Komornicką-Odmieńca Własta) w Jungowskiej mandali, odcina się od jakiejkolwiek dyskusji o płciowości innej niż duchowa:

Usiłując zrozumieć metamorfozę Komornickiej, zwraca się przede wszystkim uwagę na przemianę z kobiety w mężczyznę, a więc na pierwszy plan wysuwa się aspekt płciowy. Tymczasem wydaje się, że równorzędne znaczenie miało przeistoczenie się Marii w Piotra, a więc aspekt osobowy [... ] Dla nas ważniejszy pozostanie Piotr, a to choćby dlatego, aby jak 
najdalej znaleźć się od powierzchownych i łatwo wydawanych opinii o rzekomym transseksualizmie Komornickiej [...]. [Boniecki 1996: 54]

O ile „powierzchowne” opinie o seksualności Komornickiej-Odmieńca Własta rzeczywiście mogą razić - wystarczy przyjrzeć się internetowym dyskusjom na ten temat - o tyle zupełne wykluczenie tej problematyki poza pierwszą monografię można uznać za decyzję cokolwiek kontrowersyjną. Boniecki neguje sens dyskusji o seksualności Odmieńca, gdyż „jak najdalej” odrzuca „tatwo wydawane opinie" na ten temat. $\mathrm{Z}$ jednej strony gest ten można rozumieć jako pragnienie ograniczenia analizy do materii racjonalnie uchwytnej, obiektywnie ocenialnej i wyrażalnej. Z drugiej jednak to samo działanie równoważne jest z odrzuceniem oczekiwań czytelników jako zwyczajnego poszukiwania sensacji, podczas gdy - paradoskalnie - książka Bonieckiego dostarcza jednocześnie obszernego materiału na ten właśnie temat: wydobywa i systematyzuje szereg nieznanych dotychczas szczegółów biograficznych, przytacza niewydaną jeszcze wówczas korespondencję, odwołuje się do świadectw krewnych Komornickiej-Odmieńca Własta. Tytułowy „modernistyczny dramat ciała” sytuuje wszak wyłącznie w labiryntach psyche:

Zagadnienie płci [... ] będziemy traktować w wymiarze metaforycznym, a więc zajmować się „płcią duchową”, nie zaś seksualnością, której Komornicka wyparła się całkowicie i ostatecznie z dawnym imieniem. [Boniecki 1996: 55]

Jak zapytywała już Filipiak [2006 : 93]: skąd tak kategoryczna pewność co do cytowanej tezy („równie możliwe jest to, że własną seksualność wraz z przemianą chciała odzyskać”)? Skąd radykalna odmowa podjęcia jakiejkolwiek refleksji na ten temat? Dlaczego najlepszy bodaj znawca życia i dzieła Komornickiej-Odmieńca Własta odmawia wypowiedzi na najbardziej kontrowersyjny z tematów jej/jego dotyczących?

Pośrednią możliwość odczytania tej decyzji dostarczają oceny współczesności, które co rusz pojawiają się w książce: wzmianki 
o „ruchach feministycznych, rzekomo broniących kobiecości” [Boniecki 1996: 72], czy „społeczeństwach, które próbują uciec przed lękiem egzystencjalnym naszych czasów”, powracając „do stanu dziecięctwa" [Boniecki 1996: 84]. Przez podobne uwagi przeziera niewątpliwie niechętne nastawienie samego autora do jego własnej epoki. Stąd też, na prawach retrospekcji, interpretuje życie „Maryni” w kategoriach psychologicznych sprzed ponad półwiecza, takich jak psychoanaliza w wydaniu Carla Gustava Junga i Fromma. Komornicka-Odmieniec Włast i Jung byli niemal równolatkami (jako urodzeni odpowiednio w 1876 i 1875 r.), Fromm mógłby zaś być ich młodszym kolegą (rocznik 1900). Stąd wywodzą się też liczne polemiki z monografią Bonieckiego. O ile można się bowiem zgodzić, że odczytanie psychobiografii autorki/ autora Biesów w ramach modernistycznych dyskursów jest interesującą propozycją badawczą, o tyle trudno jednocześnie zanegować niemal pół wieku dokonań psychologii czy psychoanalizy i porzucić zupełnie dyskusję na temat seksualności autorki/autora, szczególnie dziś, w epoce „kultury wyznania” (culture of confession) [Gilmore 2001: 1-15], którą określić można i „kulturą wścibstwa”, od reality $t v$ po portale społecznościowe.

Wreszcie sam Boniecki zdaje się marginalizować w ten sposób transgresywny wobec norm i konwencji właściwych epoce wymiar życia i dzieła współautorki/współautora Forpoczt. Niezależnie od estetycznych, etycznych czy moralnych norm właściwych społeczeństwu u zarania minionego stulecia Komornicka-Odmieniec Włast przynależy wszak - choćby poprzez recepcję jej/jego życia i dzieła - do figur zapowiadających ewolucję tych właśnie norm, od społecznej, zawodowej i artystycznej emancypacji kobiet poczynając, na figurach, które oddziałują współcześnie, kończąc jak o tym świadczą właśnie owe „łatwo wydawane opinie”, odrzucane przez badacza ,jak najdalej”.

\section{Autobiograficzny nawias: wyznanie i wyzwanie}

Trzy omawiane tu pozycje badaczy wiąże niewątpliwie jedno: wszyscy wskazują (Helbig-Mischewski), podkreślają (Filipiak) bądź odrzucają (Boniecki) właściwy w szczególny sposób pisarstwu 
autobiograficznemu charakter świadectwa (jednostki) i reprezentacji (identyfikujących się z nią grup społecznych, mniejszości narodowych, seksualnych etc.), który uwidocznia najlepiej recepcja. Jak stwierdza w swojej pracy Leigh Gilmore, pisarstwo auto/ biograficzne (auto/biographical writings) - pod tym pojęciem ujmowane są biografie, autobiografie, pamiętniki, korespondencja i dzienniki osobiste - nie tylko jest nośnikiem świadectwa o życiu autora, ale w odbiorze dostarcza również potencjalnych wzorców zachowań. W ten sposób staje się nieraz potencjalnym nośnikiem dążeń, postulatów i żądań grup społecznych, które odnajdują się w „zaświadczonym życiem” tekście, od momentu jego włączenia w obręb pola literackiego [Gilmore 2001: 1-15 i passim]. Innymi słowy: wyznanie (nawet z odległej przeszłości) stać się może wyzwaniem (dla współczesności) [zob. Czermińska 2004].

Wydaje się, że nieodłączne od analiz życia i twórczości Komornickiej-Odmieńca Własta poszukiwanie spójności między biografią a dziełem rozumieć można w podobny sposób. Jego/jej los przekraczał (etyczne, estetyczne, medyczne... ) normy dopuszczalne w epoce, stąd połowa życia Odmieńca upłynęła między ośrodkami psychiatrycznymi a strychem rodzinnej posiadłości. Twórczość Komornickiej (nikt na poważnie nie brał Własta, odkąd wiedziano, że to kobieta [por. Filipiak 2006: 415 i nn.]) wykraczała jednocześnie poza model kreacji, jaki wiązano wówczas z pisarstwem kobiet. Stąd wywodzi się podwójne wykluczenie autorki/autora poza nawias rzeczywistości społeczno-kulturowej epoki. Jednak i dziś, nie tylko w popularnej recepcji, ale i w pracach naukowych, rozbieżność osobistych przekonań badaczy zdaje się pośrednio ożywia ten sam spór o kształt polskiej sceny literackiej, a w szczególności o miejsce kobiet w rzeczywistości społeczno-kulturowej czy debaty o pozycji mniejszości seksualnych.

Jak zauważyła już Iwasiów [2010: 8], „ostatnie pięciolecie przyniosło interpretacje prowadzone pod kątem doświadczenia biograficznego, dla którego tekst bywał szyfrem, nie zaś punktem dojścia”. Co więcej, twórczością Komornickiej-Odmieńca Własta zajmują się przede wszystkim badaczki (Izabela Filpiak, Brigitta Helbig-Mischewski, Maria Janion, Krystyna Kralkowska-Gątkowska, 
Katarzyna Lisowska, Katarzyna Naszkowska, Katarzyna Turkowska, Katarzyna Ewa Zdanowicz itd.), zainspirowane częstokroć psychoanalizą czy feminizmem. O ile analiza i interpretacja kondycji pisarki w epoce Weiningerowskiej mizoginii były niewątpliwie jednym z ich dążeń, o tyle mniej lub bardziej pośrednio zwracały tym samym uwagę na kondycję kobiet u zarania kolejnego stulecia. Tak dokonywała się różnorako przeprowadzana aktualizacja znaczenia życia i pism Komornickiej-Odmieńca Własta - wystarczy przypomnieć prowokacyjne artykuły Janion [1982, 1996] poświęcone „Tajemniczej Nielegalnej Osobie naszej historii literatury" [Janion 1996: 224], cytowane sformułowania o ówczesnej i współczesnej kondycji kobiet w rozprawie Helbig-Michalski czy podobne aluzje w pracy Filipiak. Zbliżone sformułowania odnaleźć można w licznych dziełach cytowanych autorek. Znamiennym tropem jest eksponowanie w nich (auto)profetycznego wymiaru pisarstwa Komornickiej-Odmieńca Własta:

Autorka ma profetyczny dar i jej powieść jest autobiograficzna w tym sensie, iż zapisuje ona w niej nie to, co się wydarzyło, ale co się wydarzy - później. [Filipiak 2006: 258]

[Komornicka - M.Ch.] dąży do samostanowienia i zerwania ograniczających ją więzów, stając się, jakby przedwcześnie, radykalną feministką, w życiu której wiedza wyprzedza doświadczenie, programuje życie. Pisząc Szkice i Skrzywdzo$n y c h$, jest w wieku nastoletnim. Za cztery lata wyjdzie za mąż, [...] idąc śladami swych bohaterek, opuści [...] męża. [...] [W]krótce pojawi się zapowiedziany w twórczości pęd do samozniszczenia i pisarka [... ] wyprze się widowiskowo swojej płci. [Helbig-Mischewski 2010: 182]

Jak widać w cytowanych fragmentach, teksty Komornickiej-Odmieńca Własta odczytywane są jako figura życia autorki/ autora: pośrednie świadectwo jej/jego życia. Ekspresja (i preekspresjonizm) tej poezji, siła wyznania zawarta $\mathrm{w}$ korespondencji i magnetyzm tragicznej biografii powodują, że autobiograficzny nawias interpretacyjny obejmuje całą twórczość: 
Zapewne sama wielokrotnie musiała stawić czoła zarzutom, jakimi otoczenie zadręcza jej bohaterki. [Helbig-Mischewski 2010: 154]

„Posiniaczyli, przetrzęśli, zwymyślali i puszczają ... tak z niczym ...”. Taki był właśnie stan Marii Komornickiej w roku 1907. Plus odbita w Intermezzo świadomość, że nie tyle stała się podmiotem, ile stawiała opór tym narracjom, które czyniły z niej pomiot - skandalistkę, modernistkę i kobietę o tyle fatalną, o ile przegraną. [Filipiak 2006: 375]

„Zapewne”, „taki właśnie” był jej/jego los, jak świadczą jej/ jego pisma. Wyznanie staje się zarazem wyzwaniem dla współczesności, które mniej (jak Helbig-Mischewski) lub bardziej (jak Filipiak) jawnie podejmują i rozwijają dziś badaczki. Aktualizowany i prospektywnie konfrontowany ze współczesnością los Komornickiej służy jednocześnie także przypomnieniu o kondycji kobiet ponad wiek później.

W analogiczny sposób los Komornickiej-Odmieńca Własta opisują z kolei badacze homoseksualizmu w kulturze polskiej [Tomasik 2008, 2014], których prace opierają się częstokroć na pisarstwie autobiograficznym. W przypadku Homobiografii Krzysztofa Tomasika są to przykładowo korespondencja Komornickiej-Odmieńca Własta czy też dzienniki Jarosława i Anny Iwaszkiewiczów, Ireny Krzywickiej czy Zofii Nałkowskiej. Gwałtowność reakcji, w szczególności na pierwsze wydanie książki Tomasika [2014: 10], ukazuje, że wbrew pozorom normy społeczne radykalnie się nie zmieniły $\mathrm{i}$ - jak pisze autor - podobne świadectwa pozwolą „jeszcze nie raz potrząsnąć kanonem”. Co więcej, twórczość Komornickiej-Odmieńca Własta poddawana zostaje także interpretacjom inspirowanym gender i transgender studies [Dynarski 2011; Zdan 2009], o czym mogą świadczyć prace młodych badaczy, takich jak Wiktor Dynarski czy Ian Zdan. W większości z tych lektur przedmiotem najżywszej polemiki są tezy Edwarda Bonieckiego, jakoby po wykluczeniu z pierwszej monografii problematyki płciowości i „przeanieleniu” Komornickiej niezbędne było dopełnienie i uwyraźnienie zna- 
czenia seksualności dla dzieła Komornickiej-Odmieńca Własta, jej „ucieleśnienie”.

Mniej lub bardziej otwarcie jego/jej postać staje się pośmiertnie patronką/patronem dyskusji o równouprawnieniu kobiet i mężczyzn czy prawach mniejszości seksualnych. Niezależnie od ocen naukowej powagi cytowanych tu prac, na której definitywne sformułowanie z pewnością jeszcze za wcześnie, na prawach hipotezy założyć można, że taka postać i taka debata są dziś potrzebne. Podobnie jak różnorakie próby „postmodernizowania” polskiej literatury po 1989 r. - pozwalają bowiem na rozwijanie i analityczne sprawdzenie kolejnych języków metodologicznych [zob. Bolecki 1997], ukazują coraz wyraźniej subwersywny potencjał pisarstwa autobiograficznego początku minionego stulecia, jednym słowem: wydobywają kolejne odcienie polskiej kultury. I choć tekst bywa tu „szyfrem, nie zaś punktem dojścia” [Iwasiów 2010: 8], mimo że z pewnością radykalizm propozycji interpretacyjnych można uznać nie tylko za „wścibstwo”, ale i, nieraz, za nadużycie interpretacyjne, to wydaje się, że ta niezgoda buduje bogatszy metodologicznie i interpretacyjnie obraz polskiego modernizmu. Twórczość Odmieńca pozostaje wyznaniem i wyzwaniem nie tylko dla polskiej humanistyki, ale poniekąd również i dla kultury jako takiej, a Komornicka-Odmieniec Włast - dalej „forpocztą” zjawisk w kulturze polskiej. I co do tego chyba wszyscy są zgodni.

\section{Wcielenia (polskiej) nowoczesności:} szereg pytań w miejsce konkluzji

Na zakończenie warto jeszcze zadać pytanie o wzmiankowany modernizm polski. Zagadnienie to pozwala ukazać najszersze bodaj horyzonty, na których tle możliwa będzie ocena sporów o miejsce Komornickiej-Odmieńca Własta w dziejach literatury polskiej i środkowoeuropejskiej. Zacytujmy raz jeszcze Filipiak [2006: 87], która wychodząc od twórczości Komornickiej-Odmieńca Własta w pierwszej części swojej monografii, postuluje relekturę polskiej nowoczesności kulturowej, opierając się na podobnych zjawiskach: 
Czy zatem można przeprowadzić paralelę między „polskim modernizmem", niedocenianym przez historyków literatury i zarazem interesującym dla czytelników poszukujących niekonwencjonalnych rozwiązań, a recepcją twórczości Marii Komornickiej? A może właśnie w modernizmie kryje się siła polskiej literatury, zaklęta, lecz gotowa, aby ją wywołać?

Pytanie to - poniekąd echo analogicznego pytania o „sceptyczne elementy" polskiego romantyzmu, jakie w tym samym czasie zadawała wraz z autorami tomu Romantyzm i nowoczesność Agata Bielik-Robson [2009: 64] - ma oczywiście charakter nie tyle interpretacji, ile postulatu o charakterze na wpół naukowym, na wpół ideologicznym. Przywołuje zarazem obszerną debatę na temat polskiego modernizmu, która toczy się przynajmniej od pracy Ryszarda Nycza [1997] po syntezę Włodzimierza Boleckiego [2012; zob. Chmurski 2013]. Nie miejsce tu i czas na jej omawianie, chciałbym więc tylko zwrócić uwagę na szczególną rolę, jaką zdaje się w niej odgrywać stopniowa rehabilitacja autorów uprzednio mniej docenianych [zob. Mencwel 2006: 286-303], a zwłaszcza na coraz większe znaczenie pisarstwa autobiograficznego. Jego analizy i szersza recepcja dalej stanowią wszak przedmiot pełnych napięcia dyskusji. Przypomnijmy chociażby niedawne spory o etyczne i estetyczne przesłanki wydawców takich dzieł, jak Kronos Witolda Gombrowicza, Dzienniki Marii Dąbrowskiej czy Jarosława Iwaszkiewicza. W tym kontekście zarysowuje się zjawisko jeszcze szersze, znaczące dla ewolucji badań nad literaturą i kulturą polską ostatnich dwóch stuleci: sprzężenie renesansu badań nad modernizmem largo sensu, tj. rewizji dziedzictwa literatury i kultury XIX i XX w., z bujnym rozwojem badań nad pisarstwem autobiograficznym. Tak pojawia się szereg pytań, na które odpowiedź mogą przynieść nawet nie tyle najbliższe lata, ile dekady:

- Czy „polowanie na modernizm(y) i modernistów” zajęło miejsce „polowania na postmodernistów”, o którym pisał Bolecki [1997]?

- Czy wzrost zainteresowania pisarstwem autobiograficznym i dorobkiem modernizmu w Polsce łączy się z poszukiwaniem 
kontrkanonu i próbą rewizji dorobku polskiej kultury ostatnich dwóch stuleci w świetle wyzwań współczesności?

- Czy zainteresowanie świadectwami życia z (nie)odległej przeszłości można z kolei odczytać jako element współczesnej „kultury wyznania”, w której autobiografizm stał się wszędobylskim dyskursem, a eksponowanie intymności niemal regułą [Gilmore 2001; Taylor 2009]?

- Czy nawrót do podobnych zapisków służy oswajaniu, odbrązowianiu czy też negocjowaniu miejsca dla intymności w dobie płynnej nowoczesności?

Podobne pytania można mnożyć.

Już dziś uznać można z pewnością, że spór o życie i twórczość Komornickiej-Odmieńca Własta pozwolił na wprowadzenie do polskiego literaturoznawstwa licznych nowych języków interpretacji, toteż zajmuje ważkie miejsce na mapie polskich poszukiwań (po)nowoczesnej tożsamości kulturowej. Podobnie jak w przypadku szeregu legendarnych autorek i autorów początku wieku, których kontrowersyjna obecność ożywia dyskusje badawcze nie tylko w Polsce, ale i w regionie, odkrywanie kolejnych wcieleń (polskiej) nowoczesności okazuje się okazją zarówno do rewizji kanonicznego spojrzenia na dzieje poszczególnych literatur, jak i do poszukiwania kolejnych języków interpretacyjnych zdolnych pochwycić jej specyfikę. Przywołać tu można przykład węgierskiego pisarza o bujnej biografii - psychiatry, morfinomana, mordercy własnej żony i samobójcy - Gézy Csátha (1887-1919). Od końca lat 70. XX w. wydania jego odkrywanych stopniowo pism (fikcji, dziennika, a także na wpół autobiograficznych pism psychoanalitycznych) generowały potrzebę wprowadzania innowacyjnych metodologii, inspirowanych antypsychiatrią, odkryciami psychoanalizy, mediologią, feminizmem czy gender studies [zob. Chmurski 2015; Szajbély 2015]. Różnice ujęć i kontrowersje badawcze zaowocowały po latach próbą stworzenia kompletnej edycji krytycznej dzienników Csátha, która uzupełniłaby częściowe i niepełne wydanie dokonane w serbskiej Wojwodinie [Csáth 2013]. Pozostaje nam mieć nadzieję, że debaty, kontrowersje i „wścibstwa” badaczy życia i dzieła Komornickiej-Odmieńca Własta już 
wkrótce doprowadzą do pełnego wydania jego/jej pism. Dopiero wówczas debaty o znaczeniu jego/jej twórczości w kulturze polskiej dobiegną być może końca.

\section{Bibliografia}

Bielik-Robson Agata (2009), Racjonalność romantyzmu, w: Romantyzm i nowoczesność, red. Michał Kuziak, Universitas, Kraków, s. 57-70.

Bogaert Catherine i Lejeune Philippe (2003), Un journal à soi. Histoire d'une pratique, Textuel, Paris.

Bogaert Catherine i Lejeune Philippe (2005), Le Journal intime. Histoire et anthologie, Textuel, Paris.

Bolecki Włodzimierz (1997), Polowanie na postmodernistów (w Polsce) i inne szkice, Wydawnictwo Literackie, Kraków.

Bolecki Włodzimierz (2012), Modalności modernizmu. Studia, analizy, interpretacje, Wydawnictwo IBL, Warszawa.

Boniecki Edward (1996), Modernistyczny dramat ciała. Maria Komornicka, Wydawnictwo IBL, Warszawa.

Chmurski Mateusz (2013), Modernizm(y) Europy środkowej? Rekonesans, „Przegląd Filozoficzno-Literacki”, nr 1-2 (36), s. 395-419.

Chmurski Mateusz (2015), Rąbek nieskończoności, „Literatura na Świecie", nr 3-4, s. 342-363.

Csáth Géza (2013), Méla akkord: hínak lábat mosni. Csáth Géza gyerek-és ifjúkori naplója 1897-1904, Magvető, Budapest.

Czermińska Małgorzata (2004), Autobiograficzny trójkąt: świadectwo, wyznanie i wyzwanie, Universitas, Kraków.

Dernałowicz Maria (1977), Piotr Odmieniec Wtast, „Twórczość”, nr 3, s. 75-78.

Dynarski Wiktor (2011), Analiza wybranych badań nad ptciowościa

Piotra Wtasta z perspektywy transgender studies, [praca magisterska na kierunku filologia polska napisana pod kierunkiem dr. hab. Jana Potkańskiego, Wydział Polonistyki, Uniwersytet Warszawski], Warszawa, [dostęp: 6 stycznia 2016], https://www.academia.edu/3646878/Analiza_wybranych_ bada\%C5\%84_nad_p\%C5\%82ciowo\%C5\%9Bci\%C4\%85_ Piotra_W\%C5\%82asta_z_perspektywy_transgender_studies.

Filipiak Izabela (2006), Obszary odmienności. Rzecz o Marii Komornickiej, słowo/obraz terytoria, Gdańsk.

Gilmore Leigh (2001), The Limits of Autobiography, Cornell University Press, Ithaca (NY). 
Helbig-Mischewski Brigitta (2010), Strącona bogini. Rzecz o Marii Komornickiej, przeł. Katarzyna Długosz, Brigitta Helbig-Mischewski, Krzysztof Putkański, Universitas, Kraków.

Iwasiów Inga (2010), Co jeszcze daje nam Komornicka?, w: Brigitta Helbig-Mischewski, Stracona bogini. Rzecz o Marii Komornickiej, Universitas, Kraków, s. 7-13.

Janion Maria (1982), Gdzie jest Lemańska?, w: Odmieńcy. Transgresje, red. Maria Janion, Zbigniew Majchrowski, Wydawnictwo Morskie, Gdańsk, s. 186-239.

Janion Maria (1996), Maria Komornicka in memoriam, w: tejże, Kobiety i duch inności, Sic!, Warszawa, s. 241-318.

Komornicka Maria (2011), Listy, red. Edward Boniecki, Muzeum Historyczne m. st. Warszawy, Warszawa.

Mencwel Andrzej (2006), Wyobraźnia antropologiczna. Próby i studia, Wydawnictwo Uniwersytetu Warszawskiego, Warszawa.

Nycz Ryszard (1997), Język modernizmu, Wydawnictwo Fundacji na Rzecz Nauki Polskiej, Wrocław.

Paczoska Ewa (2010), Prawdziwy koniec XIX wieku. Śladami nowoczesności, PIW, Warszawa.

Paczoska Ewa (2011), Gdzie jest Komornicka? w: Przerabianie XIX wieku. Studia, red. Ewa Paczoska, Bartłomiej Szleszyński, pIw, Warszawa, s. 17-41.

Paczoska Ewa i Szleszyński Bartłomiej, red. (2011), Przerabianie XIX wieku. Studia, PIw, Warszawa.

Pigoń Stanisław (1964), Trzy świadectwa o Marii Komornickiej, „Archiwum Literackie”, t. 8, s. 341-353.

Podraza-Kwiatkowska Maria (1969), Tragiczna wolność. O Marii Komornickiej, w: tejże, Młodopolskie harmonie i dysonanse, PIw, Warszawa, s. 137-168.

Podraza-Kwiatkowska Maria (1996), Wstęp, w: Maria Komornicka, Utwory poetyckie proza i wierszem, Wydawnictwo Literackie, Kraków, s. 5-41.

Rodak Paweł (2011), Między zapisem a literaturą. Dziennik polskiego pisarza w xx wieku, Wydawnictwa Uniwersytetu Warszawskiego, Warszawa.

Szajbély Mihály (2015), Géza Csáth, diarysta, przeł. Miłosz Waligórski, „Literatura na Świecie”, nr 3-4, s. 209-220.

Taylor Chloë (2009), The Culture of Confession from Augustine to Foucault: a Genealogy of the Confessing Animal, Routledge, New York.

Tomasik Krzysztof (2008), Homobiografie, Wydawnictwo Krytyki Politycznej, Warszawa. 
Tomasik Krzysztof (2014), Homobiografie, wyd. 2 poszerz.,

Wydawnictwo Krytyki Politycznej, Warszawa.

Wołosiuk Ryszard (2010), Przemoc interpretacji. Praktyki przemocy $w$ dyskursie literaturoznawczym na podstawie analiz „Biesów” Marii Komornickiej, „Polisemia. Czasopismo Naukowe Antropologów Literatury Uniwersytetu Jagiellońskiego”, nr 1, [dostęp : 1 września 2015], http://www.polisemia.com.pl/numery-czasopisma/numer-12010-1/przemoc-interpretacji.

Zdanowicz Katarzyna Ewa (2004), Kto się boi Marii K.? Sztuka i wykluczenie, Gnome, Katowice.

Zdan Ian (Zdanowicz Anna) (2009), L'apprivoisement de l'aliénation. Les démons de Maria Komornicka en tant que l'autobiographie symbolique fictive, [praca magisterska w ramach podwójnego dyplomu Master franco-polonais, UfR d'Études slaves - Wydział Polonistyki, Université Paris-Sorbonne - Uniwersytet Warszawski].

\section{Mateusz Chmurski}

Trans/figurations of modern times? Disputes over the works of Maria Komornicka/Piotr Odmieniec Włast

The article is a reflection of how the work by Maria Komornicka/Piotr Odmieniec Włast was perceived in the past two decades on the basis of an analysis of a monograph by Edward Boniecki (1996), Izabela Filipiak (2006) and Brigitta Helbig-Mischewski (2010) in the context of changes in the interpretation of modern Polish literature. In the article, attention is drawn to three groups of issues which can only be identified on the basis of contemporary perception, incomplete as it is, due to the fact that all the works of Komornicka have not been published. The forms and meaning of broadly defined autobiographical writing has been re-defined, while Polish and regional literary modernism has been revised together with the involvement of literary researchers in the subject of their analyses. The author of the article suggests a schematic differentiation between updating, prospective and retrospective strategies in Komornicka's work and a reflection on the indirect involvement in social and cultural discourses and discussions developed by contemporary researchers into Komornicka's work.

Keywords: modernism; modernity; auto-biographism; historiography; Maria Komornicka; Piotr Odmieniec-Włast; Edward Boniecki; Izabela Filipiak; Brigitta Helbig-Mischewski; Maria Janion. 
Mateusz Chmurski - doktor nauk humanistycznych (2012) na podstawie pracy Figury nowoczesności. Teoria i praktyka tekstu w literaturach Europy środkowej (1900-1914) w ramach umowy o współpromotorstwie między Uniwersytem Warszawskim a Université Paris-Sorbonne. Pracuje jako asystent w Katedrze Polonistyki i Bohemistyki Université de Lorraine (Nancy) oraz jako asystent koordynatora projektu NPRH Problemy literatury i kultury modernizmu Europy Środkowo-Wschodniej na Uniwersytecie Warszawskim. Redaktor tomów: Modernizm [y] Europy środkowo-Wschodniej, „Przegląd Filozoficzno-Literacki” 2013, nr 1-2 (36) (z Ewą Paczoską) oraz Karol Irzykowski, La Chabraque. Les Rêves de Maria Dunin (2013; przekład i opracowanie nowej francuskiej edycji Pałuby oraz fragmentów dziennika Irzykowskiego; z Kingą Siatkowską-Callebat i Patrickiem Rozborskim). 